\title{
APPLICATIONS OF NEW LABORATORY MARKER ASSAYS IN NEUROLOGICAL DIAGNOSES - A PILOT STUDY
}

\author{
David Stejskala*, Jitka Vavrouškováb, Jan Marešc, Karel Urbánek $^{c}$
}

\author{
${ }^{a}$ Department of Laboratory Medicine, Šternberk Hospital \\ ${ }^{b}$ Department of Neurology, Šternberk Hospital \\ c Institute of Neurology, Teaching Hospital, Palacký University Olomouc, Czech Republic \\ e-mail:david.stejskal@quick.cz
}

Received: September 26, 2005; Accepted (with revisions): November 11, 2005

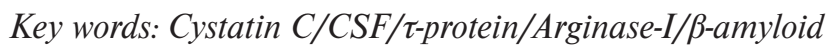

225 consecutive patients with different neurological diseases and 101 individuals as the control were examined between 2002-2004. Cystatin C, arginase-I, $\tau$-protein and $\beta$-amyloid were measured. Individuals with CNS inflammation had significantly lower Cystatin-C index (CSF/serum) values. There was no diagnostic significance of the Arginase-I assay in CSF was verified. The CSF $\tau$-protein/ $\beta$-amyloid index was shown to be a sufficient efficacy for neurodegenerative disease diagnosis.

\section{INTRODUCTION}

There is much current information on the use of new laboratory markers in the diagnosis of some neurological diseases primarily about degenerative and inflammatory origin.

Simple analysis of cerebrospinal fluid (CSF) laboratory markers has only limited significance but recently published information deals with diagnostic use of the entire CSF markers.

The first aim of our work was diagnostic evaluation of CSF cystatin $\mathrm{C}$ and arginase-I analysis in individuals with various neurological diagnoses.

The second aim of our work was evaluation of previously published diagnostic efficacy of CSF $\tau$-protein/ $\beta$-amyloid index in patients with neurodegenerative diseases.

\section{METHODS}

225 consecutive patients and 101 individuals without neurological diseases from the clinical departments of the Sternberk Hospital and the Institute of Neurology Faculty Hospital Olomouc were examined between 2002-2004.

The groups were divided into 9 subgroups ( 1 -ischemic stroke, $n=12$; 2-hemorrhagic stroke, $n=13$; 3-sclerosis multiplex-RS, $n=37$; 4-bacterial CNS inflammation, $n=11 ; 5$ serous CNS inflammation, $n=24$; 6-polyradiculoneuritis, $\mathrm{n}=13$; 7-Alzheimer disease, $\mathrm{n}=34$; 8-individuals without important neurological abnormalities, $n=101$; 9-neuropathy, $\mathrm{n}=29$ ).

CSF samples were drawn from the patients for diagnostic reasons. The serum and $\mathrm{Cfs}$ samples were separated in a cooled centrifuge at $4{ }^{\circ} \mathrm{C}$ with $3000 \mathrm{~g}$ and subsequently frozen at $-80{ }^{\circ} \mathrm{C}$ for ELISA analysis.
CSF total $\tau$-protein (ELISA, Biosource, UK) CSF $\beta$ amyloid (ELISA, Innogenetics, Belgium), CSF Arginase-I (ELISA, Biovendor, Brno, the Czech Republic), serum and CSF Cystatin-C concentrations (ELISA, Biovendor, Brno, The Czech Republic) were performed on all individuals, too. Cystatin $\mathrm{C}$ was determined with satisfying analytical parameters (intrassay coefficient of variation $(\mathrm{CV})=4.9 \%$, interassay $\mathrm{CV}=9.1 \%)$. Concentrations of Arginase-I, Cystatin C, total $\tau$-protein and $\beta$-amyloid were determined after defrosting during the course of one day.

The study was approved by the ethics commission of the Hospital Šternberk and the Medical Faculty UP Olomouc.

The data obtained were processed by means of the software Medcalc (Medcalc, Mariakerke, Belgium). The value $p<0.05$ was considered as statistically significant.

\section{RESULTS}

Cystatin-C in serum: individuals with neurodegenerative diseases (NDD, $n=34$ ) had the lowest Cystatin-C values of all subgroups (median $0.69 \mathrm{mg} / \mathrm{l}$ ) but values did not significantly differ between groups.

Cystatin-C in CSF: values did not significantly differ.

Cystatin C index: individuals with CNS inflammation had significantly lower values than individuals without neurological diseases (median 2.5 vs $4.9 ; \mathrm{p}=0,001$ ). Diagnostic sensitivity of the Cystatin-C index was $85 \%$, specificity $54 \%$ (AUC 0.76 ; $95 \%$ CI $0.64-0.83$ ) for CNS inflammation (Fig 1).

Diagnostic efficacy for polyneuropathy diagnosis was not sufficient.

Arginase-I in CSF: no significant differences were detected in concentrations between groups. $57 \%$ of 


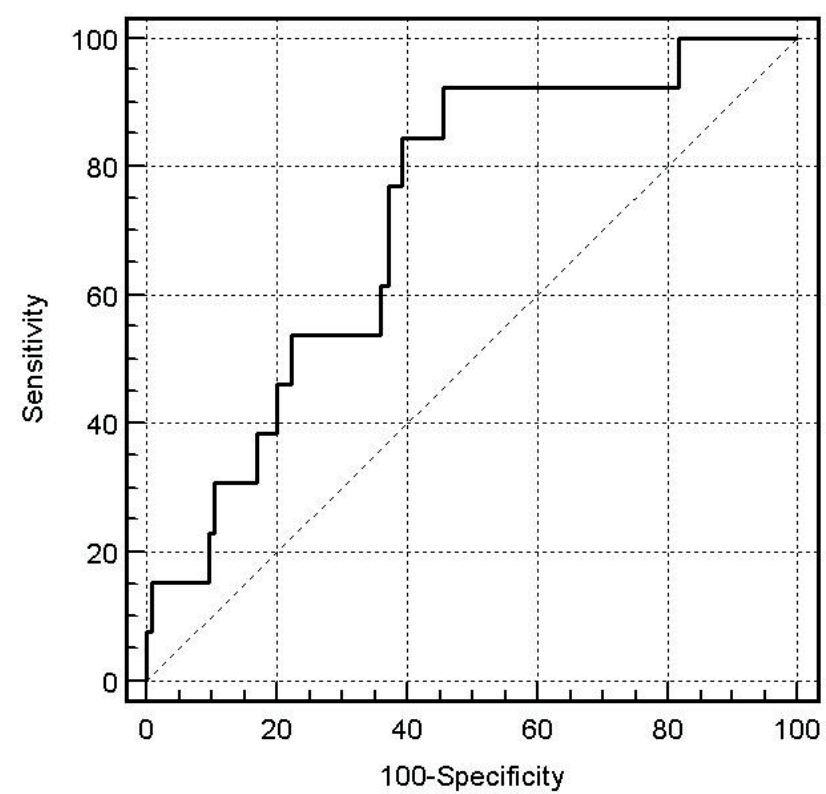

Fig. 1. Index Cystatin C ROC for CNS inflammation

individuals with CNS inflammation had measurable Arginase-I concentrations, $33 \%$ of individuals without CNS inflammation had measurable ArginaseI concentrations. No significant correlations between Arginase-I and other markers were demonstrated.

As a secondary finding we also show significant diagnostic efficacy of $\tau$-protein $/ \beta$-amyloid indexes in patients with neurodegenerative CNS diseases; diagnostic sensitivity in index value $>0.5$ was $69 \%$ and specificity $74 \%$ (AUC 0.76) (Fig. 2).

No significant differences were detected in ROC comparison of indexes $\tau$-protein/ $\beta$-amyloid and Hulstaert calculation (ROCs AUC 0.88 vs 0.88).

\section{CONCLUSIONS}

Individuals with CNS inflammation have significantly lower Cystatin- $\mathrm{C}$ index values. Cystatin- $\mathrm{C}$ index assay is for inflammation CNS diagnosis sufficiently effective. No diagnostic significance of Arginase-I assay in CSF was verified in patients with inflammatory or autoimmune CNS diseases. $\tau$-protein/ $\beta$-amyloid index in CSF was proven to be a sufficient efficacy for NDD diagnosis.

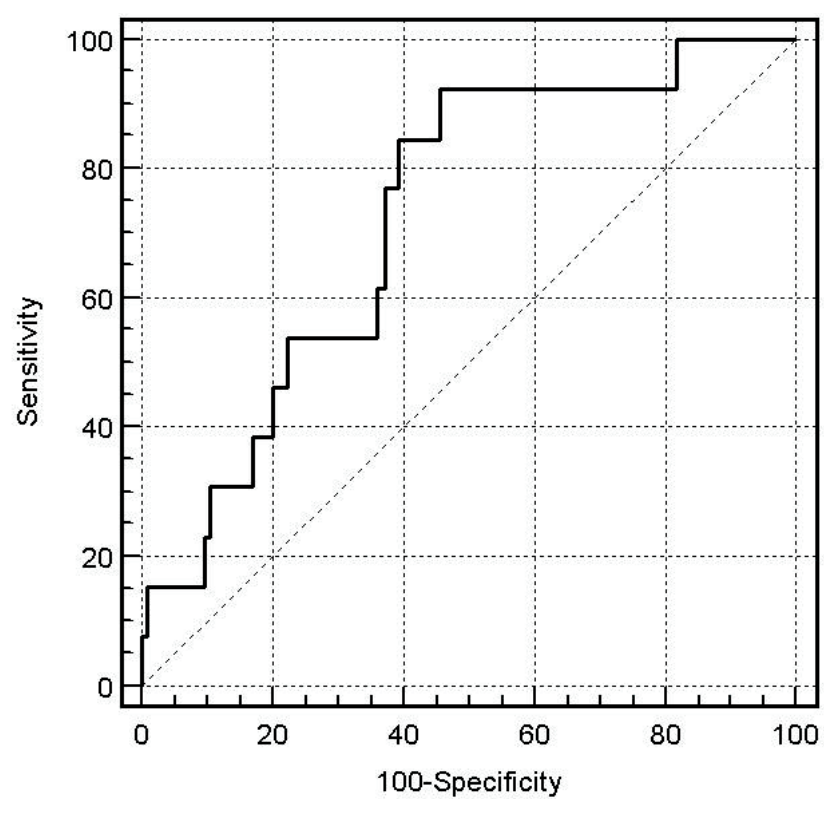

Fig. 2. Index Csf $\tau$-protein/ $\beta$-amyloid ROC for neurodegenerative CNS diseases

\section{AKNOWLEDGEMENT}

This study was supported by grant IGA NF/7480-3 from the Ministry of Health of the Czech Republic.

\section{REFERENCES}

1. Mareš J, Stejskal D, Vavroušková J, Urbánek K (2003) Use of cystatin $\mathrm{C}$ determination in clinical diagnostics. Biomed papers, 147, 177-180.

2. Lingyun XU (2003) Arginase and autoimmune inflammation in the central nervous system. Immunology, 110, 141-148.

3. Deng A, Irizarry M, Nitsch R, Growdon J, Rebeck W (2001) Elevation of cystatin C in susceptible neurons in Alzheimer's disease. American Journal of Patology, 159, 1061-1068.

4. Reiber H (2001). Dynamics of brain-derived proteins in cerebrospinal fluid. Clinica Chimica Acta, 310, 173-186.

5. Glosová L, Hort J, Bojar M, Škoda D (2004) Vyšetřování celkového tau proteinu, phospho-tau proteinu a beta-amyloidu v mozkomíšním moku - naše první zkušenosti. Klin. Biochem. Metab, 2, 113116.

6. Hulstaert F, Blennow K, Ivanoui A (1999) Improved discrimination of $\mathrm{AD}$ patients using beta-amyloid and tau levels in cerebrospinal fluids. Neurology, 52, 1555-1562. 